\title{
Liderança e Sustentabilidade dos Resultados
}

Hoje no Brasil temos mais de 16 milhões de empresas, e com a maior representatividade as de pequeno e médio porte, atualmente com um cenário econômico e político instável faz com que aumente os desafios das empresas em relação a sua gestão, tendo essas que majorar sua capacidade de inovação e administração para dar sustentabilidade nos seus resultados e assim sobreviver com o cenário. Ainda há um grande índice de falência de empresas e o principal motivo está ligado a falta de planejamento, o que me leva a pensar na nova geração de empreendedores e que no qual estes tem uma característica importantíssima que é a de saber calcular os riscos, fazendo com que diminua as chances de insucesso em seu negócio, pois abrir uma empresa é fácil o desafiador é dar sustentabilidade para ela, ou seja, fazer com que ela permaneça em "pé". Estar à frente de uma empresa exige dedicação, conhecimento, habilidades de um líder estratégico, gerencias uma empresa em um cenário onde a economia vai bem, cenário político bom é "fácil" os líderes que gerenciam suas empresas nos dias em que vivemos e estão sobrevivendo esses sim são sem nenhuma dúvida lideres estratégicos pois este tem a capacidade de prever, imaginar, manter a flexibilidade, pensar estrategicamente, tem visão de futuro e sempre está aberto para mudanças e todas essas habilidades são essenciais para dar sustentabilidade em um negócio.

A capacidade de transformar pessoas está na essência de um líder, chamamos de líder transformacional no qual para este há quatro característica sendo a primeira o carisma, e esta é o que impulsiona as pessoas a segui-lo, alguns componentes do carisma são autoconfiança, capacidade de compreender as pessoas, capacidade de se comunicar, capacidade de conhecer a si mesmo e a capacidade de realizar, em segundo lugar está a visão, pois lideres transformacionais são capazes de articular uma visão de mudança em seus liderados, a terceira característica fica com o objetivo comum, e a quarta fica por conta da inspiração e nada mais satisfatório para um líder do que ser inspirar seus liderados a darem o melhor de si a se desafiarem e fazerem acontecer por meio de suas habilidades, os lideres transformacionais proporciona aos seus liderados momentos de aprendizado não para criar seguidores mais sim novos líderes, e para você entender melhor vou citar apenas um exemplo de líder transformacional sendo este Jesus Cristo sendo este um modelo perfeito a ser seguido.

Iniciei um processo de transformação dentro da minha empresa e de imediato obtive um resultado fantástico, sempre aprendi sobre a eficiência do famoso feedback, no qual este tem por significado retorno sobre uma tarefa executa que pode ser positivo ou negativo, bom feedback analisamos o passado, ou seja, não tem como mudarmos ou fazermos diferente, e em várias pesquisas essa ferramenta não é tão eficiente. Hoje conhecemos uma outra ferramenta denominada por feedforward que visa o futuro, o que podemos fazer de diferente? Qual é o melhor caminho? Como eu líder posso ajudar? Dessa forma otimizando o potencial de cada colaborador e de maneira estratégica trazer o resultado com mais eficiência e eficácia. Orientei ao meu nosso diretor de negócios que fizéssemos o uso do feedforward com a área dele, o resultado foi surpreendentemente fantástico pois observamos que os colaboradores já de primeiro momento trouxe ideias para solucionarmos problemas, ao perguntarmos como nós diretores poderia ajuda-los e seus desafios fez com que eles se sentisse importantes dentro da empresa trazendo para eles uma segurança e em uma hora de reunião alinhamos toda estratégia da semana de forma que ao analisarmos os resultados nos surpreendemos. Ensinamos a eles que a direção é mais importante que velocidade e ao criarmos juntos essa direção fez com que a qualidade das entregas aumentassem significativamente e não imaginaríamos que a mudança de ferramenta que usávamos para acompanhamento desse um resultado tão rápido e eficiente.

As empresas sempre procuram uma interação de seus colaboradores bem como de suas áreas visando uma comunicação eficiente entre estes para que reflita positivamente no resultado final. Ao que parece ser simples como uma reunião se não for realizada com técnicas não terá um 
efeito positivo, dessa forma descreverei alguns pontos de atenção para que nós lideres tenhamos um resultado positivo ao realizar uma reunião. Existe três tipos de reuniões sendo elas reuniões informativa com o intuito de informar fatos e dados para a equipe, reuniões deliberativas esta está voltada para o intuito de tomada de decisão, e reuniões avaliativas com o intuito de verificação de resultados. Quando o assunto é a periodicidade de reuniões temos três parâmetros a seguir, primeiro reuniões regulares como o próprio nome já diz feita todos os dias com a equipe em pé com no máximo dez minutos de duração essas reuniões são para alinhar alguns assuntos específicos com equipe dar resumidamente um feedback do dia anterior e o planejamento do dia. Em segundo lugar temos as reuniões periódicas no qual essas são semanais ou quinzenais também com o intuído de alinhamentos de estratégias, analise de resultados. Em terceiro lugar temos as reuniões emergenciais no qual são tratados assuntos de suma importância e que como o próprio nome já diz são assuntos de urgências. A dica é nunca vá para uma reunião sem saber qual é a pauta, é importante que o líder distribua entre os integrantes da reunião papeis como por exemplo colocar um integrante como coordenador da reunião no qual este lera as pautas a serem discutidas, uma outra pessoa como registrador (a) no qual está será responsável por fazer as anotações pertinentes ao assunto discutidos e por último o controlador de tempo, que no qual este ficara responsável por avisar as equipes dos horários, lembrando que para que uma reunião tenha uma boa absolvição a mesma terá que ter uma duração de no máximo uma hora e meia. Importante também que esses papeis sejam rotativos entre os participantes da reunião.

Sempre que vamos discutir algum assunto ou estratégia e que precisamos tomar uma rescisão em equipe alguns líderes tem o péssimo habito de fazer com que essa decisão se tome por "votação" que no qual está se refere a 50\% mais 1, e sempre tem um da equipe que ficara torcendo contra o resultado da decisão já que o mesmo foi voto vencido, ou por decisão por consenso onde o líder diz 'todos entramos em um consenso?' e talvez de forma indireta acabe coagindo as pessoas que possa não consentir com aquela decisão. Então o que nos leva ao termos que realmente funciona que chamamos de tomada de decisão por concordância onde dentro dela temos uma profundidade de conhecimento técnico, dialogo, humildade de reconhecer valor no outro e a gestão do tempo características estas que faz de uma tomada de decisão eficiente e eficaz.

O sonho de qualquer líder é ter uma equipe de alta performance para isso o líder deve entender o que ele quer formar, um bando onde este se caracteriza por pessoas que pensam cada um por si e não ajuda os outros; temos grupos que são pessoas que se unem para satisfação de seus interesses que não necessariamente é o da empresa, um exemplo são pessoas ligadas a sindicados; temos as equipes que são duas ou mais pessoas com um objetivo comum sendo uma delas o líder; e por fim demos o time onde todos são líderes, sabem o porquê de tudo sabem onde querem chegar qual direção tomar e trazem resultados com qualidade. Liderar pessoas exige competências, habilidades, dedicação, conhecimento características essas que faz de um líder ser a inspiração para outras pessoas, o bom líder saber que ele está em constante aprendizado e que pode aprender tanto com o zelador da empresa quanto com seus pares e dessa entra a característica que para mim é a mais importante para um líder a humildade, essa sim faz do líder um ser diferente e quando seus liderados identifica essa característica pode ter certeza que ele está sendo o espelho para muitos. Descrevi no decorrer desses paper alguns assuntos voltado a forma de liderança e suas caraterísticas e sempre vai haver mais e mais estudos sobre o assunto de forma que teremos como responsabilidade de sempre estarmos nos atualizando, nos reciclando pois a evolução da tecnologia, das pessoas (novas gerações) nos exige buscar cada vez mais, e se nós mesmos nos desafiar alcançaremos resultados, pois são os desafios que movem pessoas ou pelo menos deviam. 